\title{
Juvenile neuronal ceroid lipofuscinosis
}

INSERM

\section{Source}

INSERM. (1999). Orphanet: an online rare disease and orphan drug data base. Juvenile neuronal ceroid lipofuscinosis. ORPHA:79264

Juvenile neuronal ceroid lipofuscinoses (JNCLs) are a genetically heterogeneous group of neuronal ceroid lipofuscinoses (NCLs; see this term) typically characterized by onset at early school age with vision loss due to retinopathy, seizures and the decline of mental and motor capacities. 